\title{
A dedifferentiated rare primary breast liposarcoma - case report and literature review
}

\author{
Valentin Nicolae Varlas ${ }^{1,2)}$, YASSin Rhazi ${ }^{1}$, OANa MARIa IONESCU ${ }^{2)}$, LUMinita Gentiana Micu ${ }^{3,4}$,

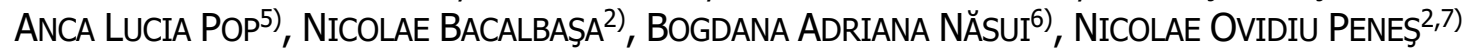 \\ 1) Department of Obstetrics and Gynecology, Filantropia Clinical Hospital, Bucharest, Romania \\ 2) Department of Obstetrics and Gynecology, Carol Davila University of Medicine and Pharmacy, Bucharest, Romania \\ 3) Department of Pathology, Emergency County Hospital, Constanţa, Romania \\ 4) Citosan Plus Laboratory, Constanta, Romania \\ 5) Department of Clinical Laboratory, Carol Davila University of Medicine and Pharmacy, Bucharest, Romania \\ 6) Department of Community Health, Iuliu Hatieganu University of Medicine and Pharmacy, Cluj-Napoca, Romania \\ 7) Department of Anesthesiology and Intensive Care, Bucharest University Emergency Hospital, Carol Davila University \\ of Medicine and Pharmacy, Bucharest, Romania
}

\begin{abstract}
Liposarcoma of the breast is a very rare soft tissue malignant tumor arising in the fat cells, with a prevalence of $0.3 \%$ of all malignant breast tumors, clinically manifested as a palpable breast mass mimicking a primary breast cancer. In the present paper, we had two objectives: (i) to report the first liposarcoma case in our Clinic and (ii) to screen the scientific literature on the topic. Our report presents an unusual case of a 56-year-old female with symptomatic left breast mass initially histopathologically diagnosed as a mesenchymal lesion. Four months later, the tumor was histopathologically identified as a grade 3 dedifferentiated liposarcoma (DDLPS) Fédération Nationale des Centres de Lutte Contre le Cancer (FNCLCC; French Federation of Cancer Centers). We present the histopathological, immunohistochemical, and radiological features of the case and outcomes. Secondly, we performed a systematic search on liposarcoma on the PubMed ${ }^{\circledR} / M^{2} d l i n e^{\circledR}$ and Web of Science ${ }^{\circledR}$ databases, using the keyword "primary breast liposarcoma" (all-time topic). Due to the small number of cases found in the literature, the best treatment choice and determination of prognosis are difficult to make. Our patient underwent breast radical surgery, received adjuvant treatment, continuously monitored, being disease-free after five years of follow-up.
\end{abstract}

Keywords: primary breast liposarcoma, breast cancer, rare malignancies.

\section{口 Introduction}

Liposarcoma is one of the most common soft tissue sarcomas (STSs) in adult people [1,2], frequently arising in the retroperitoneum and deep soft tissues of the extremities $[1,3,4]$ and rarely seen in unusual locations like the axilla, spermatic cord, vulva, or breast $[5,6]$. Despite the variable histopathological (HP) features displayed by these types of tumors, five major HP subtypes are acknowledged today by the World Health Organization (WHO): atypical lipomatous tumor/well-differentiated liposarcoma (ALT/WDLPS), myxoid liposarcoma, pleomorphic liposarcoma, dedifferentiated liposarcoma (DDLPS), and myxoid pleomorphic liposarcoma, each HP subtype having different behaviors and patterns of recurrence $[2,6,7]$.

Breast sarcomas are rare conditions [8], representing up to $0.3 \%$ of all malignant breast tumors [1], often misdiagnosed with other primary breast malignancies (carcinomas) because of their rarity and similar clinical presentations [5, 8]. Breast sarcomas are divided into three groups: primary breast sarcomas, malignant phyllodes tumors, and sarcomas arising in the post-irradiation breast $[8,9]$.

First described by Neumann, in 1862 [2], breast lipo- sarcoma accounts for $3-24 \%$ of all breast sarcomas [1], affecting more frequently females than males in their fourth to sixth decades $[5,10]$. HP characteristics (differentiation, size, grade, and type) and disease advancement are important in determining case management and prognosis $[3,4,11]$. Due to its rarity, poor response to chemotherapy and radiotherapy, it is difficult to develop guidelines for the surgical treatment and any subsequent specific therapy [10]; due to low incidence, there is a lack of literature reporting liposarcoma cases, so reporting any new case is crucial.

\section{Aim}

The purpose of this report was ( $i$ ) to describe an extremely rare case of dedifferentiated breast liposarcoma - the first case in our Clinic - and afferent therapy and, as the cases are scarce, (ii) to review the literature on the topic (objective - to update the scientific information on breast liposarcoma cases, all time).

\section{ㅁ Case presentation}

A 56-year-old woman, complaining of pain and the appearance of a tumor in her left breast for more than one month, was referred to the Department of Surgery, Medstar

This is an open-access article distributed under the terms of a Creative Commons Attribution-NonCommercial-ShareAlike 4.0 International Public License, which permits unrestricted use, adaptation, distribution and reproduction in any medium, non-commercially, provided the new creations are licensed under identical terms as the original work and the original work is properly cited. 
General Hospital, Constanța, Romania, in June 2016, for further evaluation. Breast examination showed a 4-cm tumor in the lower quadrants of the left breast, close to the skin, very sensitive during the examination, with no clinically axillary lymph nodes. The patient had no personal or family oncological history. In the Department of General Surgery of the same Hospital, a left lumpectomy was performed without axillary dissection.

Postoperative HP examination (Department of Pathology, Emergency County Hospital, Constanţa) demonstrated mesenchymal lesion and imposed the differential diagnosis between a myofibroblastic inflammatory tumor and a pseudotumor mesenchymal lesion - pseudoangiomatous stromal hyperplasia (PASH).

Four months after the surgical intervention, the patient complained of the same pain and a nodule in the same region in her left breast. In this situation, the patient presented at Emergency County Hospital, Constanţa. Thoracic magnetic resonance imaging (MRI) identified the tumor as a $46 / 42 \mathrm{~mm}$ nodule, with a polycyclic outline and irregular internal perimeter, having a heterogenous high-intensity signal on T2-weighted and heterogenous low-intensity signal on T1-weighted images, showing highintensity on diffusion-weighted imaging, suggestive for a malignant type of changes. On MRI scan, the left side axillary lymph nodes (Figure 1A) did not exceed $9 \mathrm{~mm}$ in diameter.

The next step was a Tru-Cut biopsy (TCB) of the tumor, and the HP result was a high-grade sarcoma, implying immunohistochemical (IHC) examination for the definitive diagnosis. Routine histology and immunohistochemistry were performed in Emergency County Hospital, Constanţa. Immunohistochemistry (manual technique, Biocare immunomarkers) was positive for S100 (clone 15E2E2+4C4.3), alpha-smooth muscle actin ( $\alpha$-SMA) (clone 1A4), Ki67 (clone SP6, positive in 35\% of tumor cells), and negative for pan-cytokeratin (CK) AE1/AE3 (clone AE-1/AE-3) and cluster of differentiation 34 (CD34) (clone QBEnd 10) immunomarkers. The result revealed a grade 3 DDLPS, using Fédération Nationale des Centres de Lutte Contre le Cancer (FNCLCC; French Federation of Cancer Centers) grading system, the dedifferentiated area suggesting a myxofibrosarcoma component.

One month later (November 2016), the patient was admitted to Filantropia Clinical Hospital (Bucharest, Romania), a tertiary Obstetrics and Gynecology Hospital. The breast examination revealed a $4.5 \mathrm{~cm}$ nodule in the lower quadrants of the left breast, very close to the skin, with an intense vascular pattern on Doppler ultrasound (US) and clinically axillary lymph nodes. The thoracic computed tomography (CT) scan showed a 40-50 mm necrotic lobular tumor, which developed in the left breast's inferior external quadrant, with axillary lymph nodes (Figure 1B).

The patient underwent modified radical left mastectomy (removing the left breast and the level one, level two axillary lymph nodes); the postoperative recovery was uneventful. The surgical specimen was a 45/44 mm slightly lobulated well-demarcated tumor, brown-yellow, with a firm-elastic consistency.

The specimen was processed automatically and embedded in paraffin blocks. The HP assessment [Hematoxylin-
Eosin (HE)-stained slides] and IHC examination were done using BenchMark GX Ventana System (Roche Diagnostics ${ }^{\circledR}$, Basel, Switzerland) performed in Citosan Plus Laboratory (Constanţa).
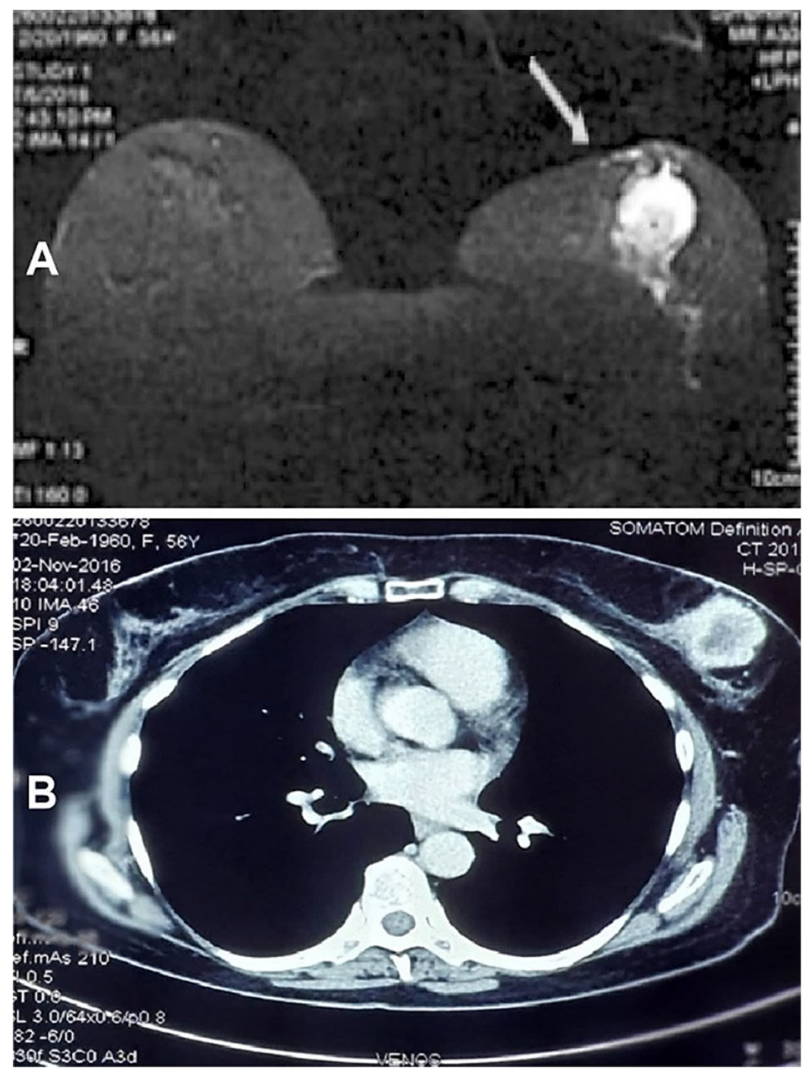

Figure 1 - (A) MRI scan identified the tumor as a $46 / 42 \mathrm{~mm}$ nodule, with a polycyclic outline and irregular internal perimeter; (B) CT scan shows a necrotic lobular tumor of 40-50 $\mathrm{mm}$, in the inferior external quadrant of the left breast. CT: Computed tomography; MRI: Magnetic resonance imaging.

The microscopic examination revealed a WDLPS, with an abrupt transition to a high-grade non-lipogenic sarcoma composed of fusiform and ovoid elongated cells, with variable nuclear atypia and numerous mitotic figures [23 mitoses/10 high-power fields (HPFs)]. A diffuse pattern was seen, with focal storiform arrangement and variable cellular density; foci with high cellularity and myxoid areas were present, together with a rich vasculature. There was necrosis in less than $50 \%$ of the tumor volume (Figure 2, A and B). Morphology corresponded to a grade 3 DDLPS FNCLCC sarcoma grading system.

The routine microscopy (Figure 3, A-D) showed a highgrade sarcomatous proliferation, with HP and IHC aspect corresponding to a DDLPS: pan-CK AE1/AE3 (clone PCK26/Ventana) negative, positive in the well-differentiated component, CD34 (clone QBEnd 10/Ventana) negative (Figure 3A), S100 (clone 4C4.9/Ventana) negative in DDLPS (Figure 3B) and, $\alpha$-SMA (clone 1A4/Cell Marque) focal positive (Figure 3C), high Ki67 (clone 30-9/Ventana) proliferation rate (Figure 3D), and p53 (clone BP53/Ventana) overexpression.

We found positive focal cells for $\alpha$-SMA, p53 overexpression, and $\mathrm{Ki} 67$ approximately $40 \%$; there was no positive immunoreaction in neoplastic cells for CD34 and S100 in DDLPS. 

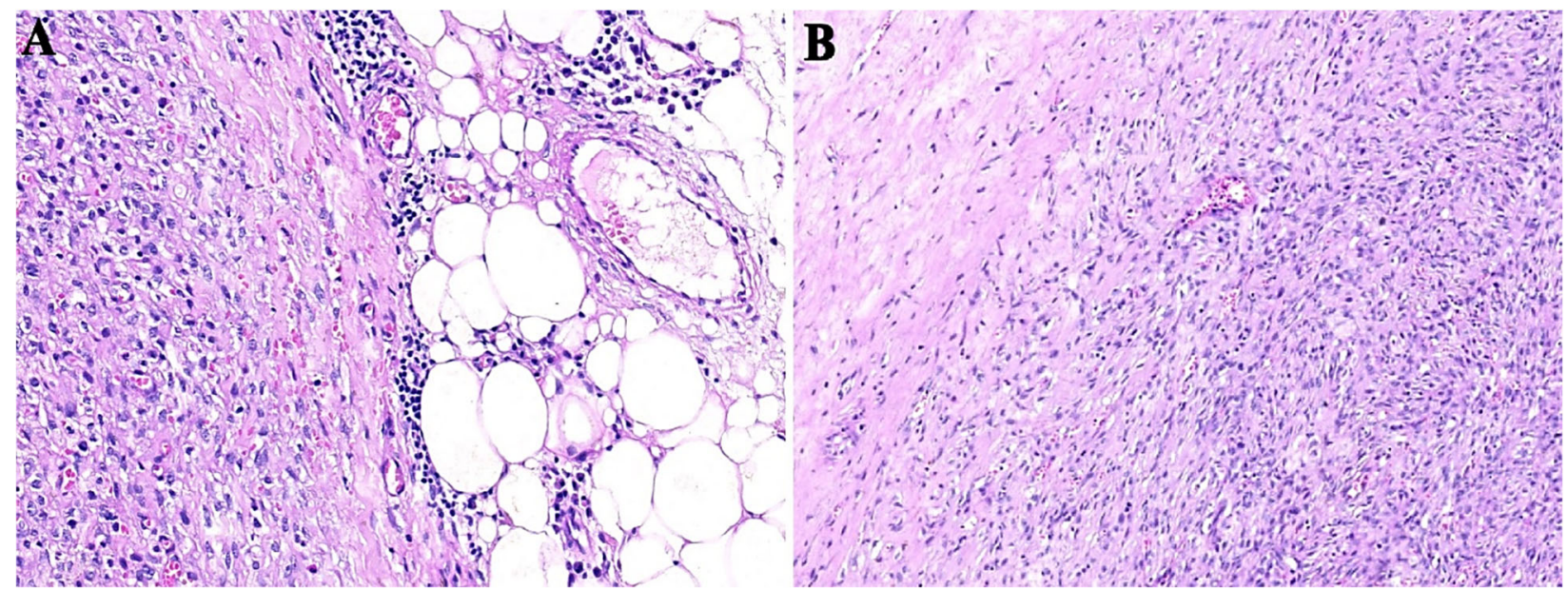

Figure 2 - Histology of the left breast specimen: (A) Transition between the well-differentiated component and the dedifferentiated component; (B) Dense cellular areas with focal storiform pattern (right) and low cellular area (left). Hematoxylin-Eosin (HE) staining: $(A) \times 100 ;(B) \times 40$.

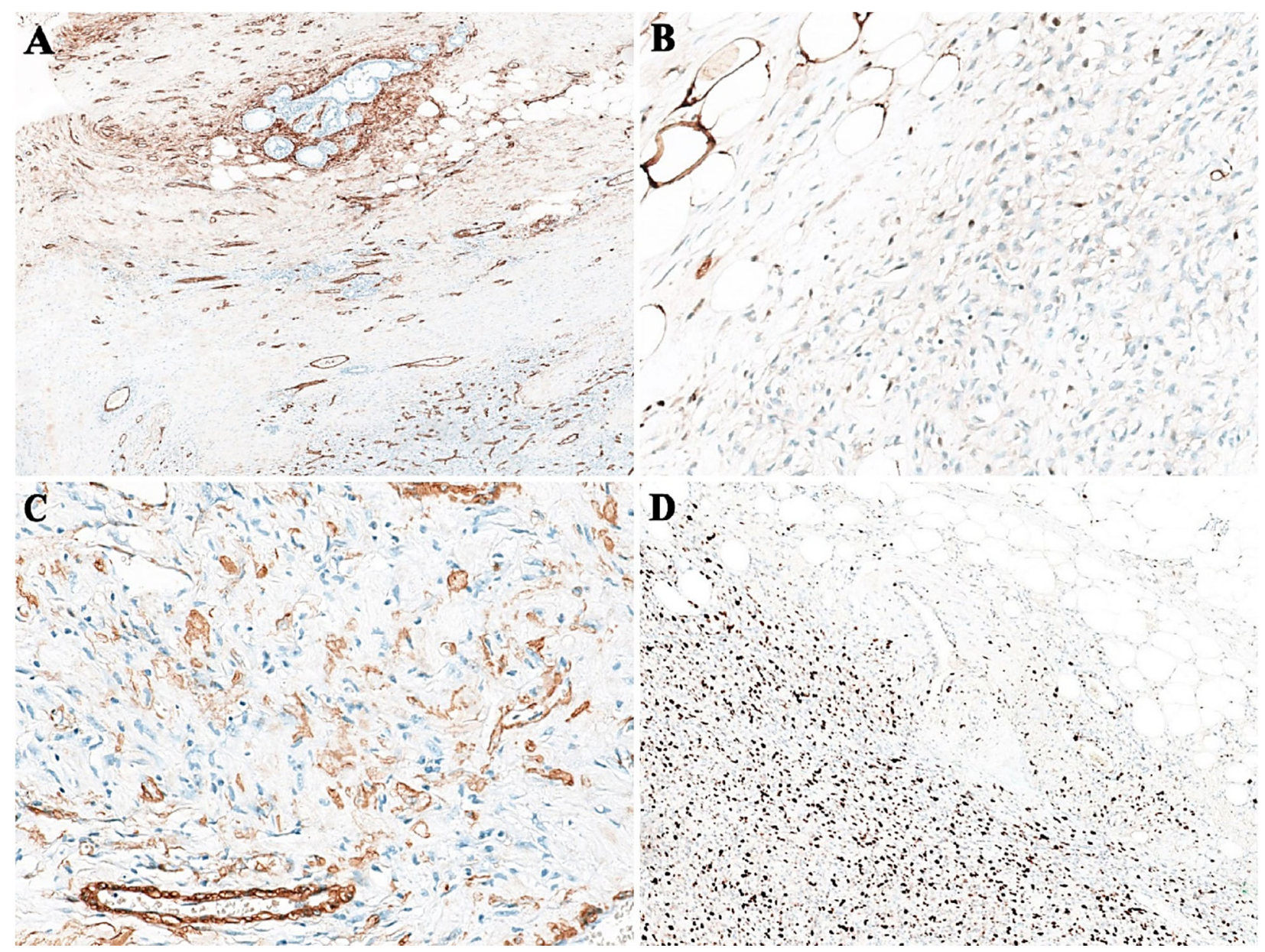

Figure 3 - Immunohistochemical analysis of the left breast demonstrated: (A) Vessel walls within tumor decorated with CD34 - neoplastic cells are CD34 negative ( $\times 40)$; (B) S100 negative in neoplastic cells $(\times 100)$; (C) Focal positivity for a-SMA in neoplastic cells (×100); (D) High Ki67 mitotic index (×100). a-SMA: Alpha-smooth muscle actin; CD34: Cluster of differentiation 34.

Postoperative HP examination proved negative margins, with no axillary lymph node involvement. The patient postoperative management included six cycles of chemotherapy with Ifosfamide, Mesna, and Doxorubicin carried out without complications. Because the tumor size was less than $5 \mathrm{~cm}$, the uncertain benefit, and the late side effects, the postoperative radiotherapy was not considered appropriate.
Local or distant metastasis was negative at a six-month follow-up CT body scan.

At present, the patient is disease-free clinically after five years of follow-up.

Informed consent was obtained from the patient involved in the study; she was apprised and signed the enrollment and publication agreement. 


\section{ㅁ Discussions}

Primary breast sarcomas are a heterogeneous group, including fibrosarcoma, angiosarcoma, leiomyosarcoma, malignant fibrous histiocytoma, osteosarcoma, rhabdomyosarcoma, and other sarcomas [6,12]. Liposarcoma is considered the most common STS. The WHO Classification in 2013 identified three HP subtypes of WDLPS: adipocytic (lipoma-like), sclerosing, and inflammatory [13].

However, breast liposarcomas are rare tumors (3-24\% of breast sarcomas) [1], generally seen in females between the ages of 45 and $55[5,10]$, although a wide age range has been reported (24-81 years) [14].

In 1887, Schmidt reported 11 cases of breast angiosarcoma, which is considered the first reported cases of primary breast sarcoma in literature [15]. Austin \& Dupree published, in 1986, one of the first series of cases of breast liposarcoma, which included 20 patients [16].

Liposarcomas rarely arise within the breast. Adem et al. reviewed the Mayo Clinic Surgical Pathology database and searched for all breast sarcomas from 1910 to 2000 . They reported that primary breast sarcomas were extremely rare, counting for no more than $0.1 \%$ of all breast neoplasms [17].

\section{Data search}

We performed a search on two databases, PubMed $^{\mathbb{R}}$ and $W$ eb of Science ${ }^{\circledR}$, published during the all-time topic, screening for the keyword "primary breast liposarcoma." We found few reports concerning primary breast liposarcoma (Table 1). We search for the keyword "primary breast liposarcoma" on the PubMed $^{\mathbb{R}}$ database retrieved 98 results filtered to 32 papers and on Web of Science ${ }^{\circledR}$ retrieved 45 results filtered to 17 papers refined to "human" and reduced to 10 papers after the exclusion of duplicates. We identified six main issues in the retrieved literature: $(i)$ clinical features of liposarcoma, (ii) HP features, (iii) molecular lesions, (iv) differential diagnosis, ( $v$ ) treatment, and (vi) prognosis of the liposarcoma.

Table 1 - Data search retrieved literature case reports on primary breast liposarcoma, in the databases (PubMed ${ }^{\mathbb{B}}$ and Web of Science ${ }^{\circledR}$ )

\begin{tabular}{|c|c|c|c|c|c|}
\hline Study & Lesion & Investigations & Treatment & Histopathology & Complications \\
\hline $\begin{array}{l}\text { Pant et al. } \\
(2008) \\
{[5]}\end{array}$ & $\begin{array}{l}\text { Right breast } \\
\text { well-defined firm, } \\
\text { mobile lump } \\
\end{array}$ & $\begin{array}{l}\text { FNA cytology and US exam: } \\
\text { diagnosis of fibroadenoma. }\end{array}$ & $\begin{array}{l}\text { Wide local excision } \\
\text { involving the neoplastic } \\
\text { margins. }\end{array}$ & $\begin{array}{l}\text { Myxoid } \\
\text { liposarcoma }\end{array}$ & $\begin{array}{l}\text { No postoperative } \\
\text { complication }\end{array}$ \\
\hline $\begin{array}{l}\text { Klopcic } \\
\text { et al. } \\
(2009) \\
{[18]}\end{array}$ & $\begin{array}{l}\text { Right breast mass } \\
10 \mathrm{~cm} \text { tumor }\end{array}$ & $\begin{array}{l}\text { Mammography: lobulated } \\
\text { fibroadenoma of } 2.5 \mathrm{~cm} \text { with } \\
\text { microcalcification that evolved } \\
\text { five months later to } 10 \mathrm{~cm} \text {. } \\
\text { FNA biopsy - myxoid primary } \\
\text { breast sarcoma. }\end{array}$ & Right mastectomy. & $\begin{array}{l}\text { Primary breast } \\
\text { myxofibrosarcoma }\end{array}$ & None \\
\hline $\begin{array}{l}\text { Nandipati } \\
\text { et al. } \\
(2010) \\
{[19]}\end{array}$ & $\begin{array}{l}\text { Right breast mass } \\
8 \mathrm{~cm} \text {, firm swelling. } \\
\text { Palpable non-tender } \\
\text { lymph node in the } \\
\text { right axilla. }\end{array}$ & $\begin{array}{l}\text { US showed an echogenic } \\
\text { mass with cystic and solid } \\
\text { areas. } \\
\text { Biopsy suggested } \\
\text { pleomorphic liposarcoma. } \\
\text { Bone scan and PET-CT - } \\
\text { no metastases }\end{array}$ & $\begin{array}{l}\text { Right mastectomy } \\
\text { with excisional biopsy } \\
\text { lymph node in the axilla } \\
\text { (negative for metastasis). } \\
\text { Chemotherapy: } \\
\text { Adriamycin and } \\
\text { Ifosfamide. }\end{array}$ & $\begin{array}{l}\text { Pleomorphic } \\
\text { liposarcoma }\end{array}$ & $\begin{array}{l}\text { Uneventful. } \\
\text { No metastasis } \\
\text { after } 12 \text { months. }\end{array}$ \\
\hline $\begin{array}{l}\text { Lee et al. } \\
(2011) \\
{[20]}\end{array}$ & $\begin{array}{l}\text { Left breast mass } \\
3 \mathrm{~cm} \text { well defined }\end{array}$ & $\begin{array}{l}\text { US and mammograms } \\
\text { classified the mass } 4 \mathrm{~b} \\
\text { (BI-RADS). } \\
\text { Guided-needle biopsy } \\
\text { did not provide a correct } \\
\text { diagnosis. }\end{array}$ & $\begin{array}{l}\text { Surgical excision } \\
\text { of a firm fleshy well- } \\
\text { circumscribed round } \\
\text { mass. }\end{array}$ & $\begin{array}{l}\text { Low grade } \\
\text { fibrosarcoma }\end{array}$ & $\begin{array}{l}\text { None. } \\
\text { No metastasis } \\
\text { after } 10 \text { months. }\end{array}$ \\
\hline $\begin{array}{l}\text { Rodríguez } \\
\text { Suárez } \\
\text { et al. } \\
(2017) \\
\text { [6] }\end{array}$ & $\begin{array}{l}\text { Left breast mass, } \\
\text { stiff nodule not } \\
\text { attached to deep } \\
\text { plans in the left } \\
\text { axillary tail of } \\
\text { Spence }\end{array}$ & $\begin{array}{l}\text { Mammography and US } \\
\text { mass with intranodal } \\
\text { calcifications. } \\
\text { Core-needle biopsy showed } \\
\text { a well-differentiated } \\
\text { liposarcoma. }\end{array}$ & $\begin{array}{l}\text { Conservative surgery } \\
\text { with the excision of a } \\
\text { well-defined nodule. } \\
\text { No axillary dissection. } \\
\text { No radiotherapy, } \\
\text { no chemotherapy. }\end{array}$ & $\begin{array}{l}\text { Malignant } \\
\text { mesenchymal } \\
\text { neoplasm with } \\
\text { lipoblasts }\end{array}$ & $\begin{array}{l}\text { None. } \\
\text { No metastasis } \\
\text { after nine } \\
\text { months. }\end{array}$ \\
\hline $\begin{array}{c}\text { Saito et al. } \\
(2013) \\
{[1]}\end{array}$ & Right breast nodule & Biopsy: myxoid liposarcoma & $\begin{array}{l}\text { Total mastectomy } \\
\text { right breast. } \\
\text { Radiotherapy ( } 60 \mathrm{~Gy}) .\end{array}$ & $\begin{array}{l}\text { Myxoid } \\
\text { liposarcoma }\end{array}$ & $\begin{array}{l}\text { None. } \\
\text { No metastasis } \\
\text { after } 20 \text { months. }\end{array}$ \\
\hline $\begin{array}{c}\text { Raj et al. } \\
\text { (2015) } \\
\text { [3] }\end{array}$ & $\begin{array}{l}\text { Right breast } \\
\text { mass associated } \\
\text { with right axillary } \\
\text { fullness }\end{array}$ & $\begin{array}{l}\text { Mammography showed } \\
\text { a } 9 \mathrm{~cm} \text { breast mass and a } \\
5 \mathrm{~cm} \text { right axillary mass. } \\
\text { Guided biopsies were } \\
\text { benign. }\end{array}$ & $\begin{array}{l}\text { Radical mastectomy } \\
\text { with resection of axillary } \\
\text { nodes and pectoralis } \\
\text { major muscle. } \\
\text { Four cycles of } \\
\text { Adriamycin, Ifosfamide, } \\
\text { Mesna. } \\
\text { Adjuvant radiotherapy. }\end{array}$ & $\begin{array}{l}\text { High grade primary } \\
\text { differentiated } \\
\text { liposarcoma }\end{array}$ & None \\
\hline $\begin{array}{l}\text { Salhi et al. } \\
\text { (2017) } \\
\text { [2] }\end{array}$ & $\begin{array}{l}\text { Median tumor size } \\
6.8 \mathrm{~cm}\end{array}$ & & $\begin{array}{l}\text { Four patients - total } \\
\text { mastectomy; local } \\
\text { radiotherapy. } \\
\text { One patient - } \\
\text { conservative surgery; } \\
\text { chemotherapy. } \\
\text { None had axillary } \\
\text { dissection. }\end{array}$ & $\begin{array}{l}\text { Pleomorphic } \\
\text { liposarcoma. } \\
\text { One myxoid } \\
\text { liposarcoma. }\end{array}$ & $\begin{array}{l}\text { None. } \\
\text { No metastasis } \\
\text { after } 56 \text { months. }\end{array}$ \\
\hline
\end{tabular}




\begin{tabular}{|c|c|c|c|c|c|}
\hline Study & Lesion & Investigations & Treatment & Histopathology & Complications \\
\hline $\begin{array}{l}\text { Nagarajan } \\
\text { et al. } \\
(2018) \\
\text { [21] }\end{array}$ & $\begin{array}{l}\text { Left breast painful } \\
\text { soft to firm lump }\end{array}$ & $\begin{array}{l}\text { US and mammography - } \\
\text { large, encapsulated fat } \\
\text { mass, with a dense irregular } \\
\text { peripheral component } \\
\text { suspicious for malignancy. } \\
\text { Guided biopsy - spindle cell } \\
\text { neoplasm. }\end{array}$ & $\begin{array}{l}\text { Wide excision of } \\
\text { the mass. PET-CT } \\
\text { showed no metastatic } \\
\text { lesion, and adjuvant } \\
\text { radiotherapy was given. }\end{array}$ & $\begin{array}{l}\text { Dedifferentiated } \\
\text { liposarcoma }\end{array}$ & $\begin{array}{l}\text { None. } \\
\text { No metastasis } \\
\text { after five years. }\end{array}$ \\
\hline $\begin{array}{c}\text { Jo et al. } \\
(2020) \\
{[22]}\end{array}$ & $\begin{array}{l}\text { Left breast mass } \\
5 \mathrm{~cm} \text { solitary }\end{array}$ & $\begin{array}{l}\text { Biopsy suspected a } \\
\text { pleomorphic liposarcoma. } \\
\text { Mammographic and } \\
\text { US findings show a fat- } \\
\text { containing density and } \\
\text { hyperechogenicity. }\end{array}$ & $\begin{array}{l}\text { Left lumpectomy without } \\
\text { axillary dissection. } \\
\text { Twelve months after, } \\
\text { a recurrent mass with } \\
\text { lumpectomy, seven } \\
\text { months later recurrence } \\
\text { for two masses with } \\
\text { modified radical } \\
\text { mastectomy. }\end{array}$ & $\begin{array}{l}\text { Pleomorphic } \\
\text { liposarcoma }\end{array}$ & $\begin{array}{l}\text { No postoperative } \\
\text { complication }\end{array}$ \\
\hline
\end{tabular}

BI-RADS: Breast imaging-reporting and data system; FNA: Fine-needle aspiration; PET-CT: Positron emission tomography-computed tomography; US: Ultrasound.

The clinical features of breast liposarcoma include unilateral slowly growing painful (or not) breast mass that rarely produces pectoral muscle invasion, skin changes or nipple retraction, exhibiting a well-circumscribed, infiltrative, or multinodular pattern of growth $[3,5,6]$; aspects that make this type of tumor often misdiagnosed or confused with other primary breast malignancies (carcinomas) [5, 8].

From the HP point of view, breast liposarcoma may arise from pre-existing benign tumors (lipomas, fibroadenomas, and phyllodes tumors) [3], directly from the mammary interlobular stromal tissue, or as a component of malignant phyllodes tumor [2, 10]. Primary breast sarcomas may spread by direct invasion or hematogenous metastasis, axillary lymph node involvement being rare [20].

The microscopic diagnosis of liposarcoma can be challenging [3]. Fine-needle aspiration (FNA) biopsy is a widely accepted and cost-effective diagnostic procedure, with high sensitivity and specificity (94\% to 99\%) in evaluating epithelial breast lesions. The usefulness of FNA in differentiating sarcomas is still low only based on cytology unless specific features are present [23]. Nevertheless, recognizing such lesions can avoid unnecessary sentinel and axillary lymph node dissection [18]. Breast sarcoma is diagnosed by core or excisional biopsy [11].

The differential diagnosis of breast liposarcoma includes undifferentiated pleomorphic sarcoma, fat necrosis, silicon granuloma, and signet ring cell carcinoma [2, 5]. Before diagnosing any breast tumor as a primary sarcoma, it is important to exclude metaplastic carcinoma by extensively sampling the tumor to identify foci of conventional invasive mammary carcinoma and/or ductal carcinoma in situ and by conducting immunostainings using multiple CK antibodies [24]. The main features useful in differentiating liposarcoma from other types of sarcomas are based on recognizing the typical lipoblasts with scalloped, irregular, hyperchromatic nuclei with sharply defined intracytoplasmic vacuoles, that stain positive with $\mathrm{S} 100[2,4]$. Immunohistochemistry tests for desmin, vimentin, $\alpha$-SMA, CK, leukocyte common antigen (LCA), CD34, human melanoma black 45 (HMB45), epithelial membrane antigen (EMA), and S100 should be analyzed in sarcomas to rule out another type of tumors (non-mesenchymal malignant tumors or sarcomas with a specific line of differentiation)
[4]. $M D M 2$ gene amplification analysis represents the standard differential diagnosis of ALT/WDLPS and DDLPS $[25,26]$.

Liposarcomas have specific molecular lesions that define their subtypes [24]. More than 95\% myxoid/round cell liposarcomas have either the characteristic $\mathrm{t}(12 ; 16)(\mathrm{q} 13 ; \mathrm{p} 11)$ or $\mathrm{t}(12 ; 22)(\mathrm{q} 13 ; \mathrm{q} 12)$ chromosomal translocation that results in the fusion of translocated in liposarcoma (TLS)-CCAAT enhancer binding protein (C/EBP) homologous protein (CHOP) or Ewing sarcoma breakpoint region 1 (EWSR1)CHOP $[1,24]$. In contrast, WDLPS or DDLPS display amplification of chromosome locus 12q13-15, and contain several amplified genes, including $M D M 2$, carboxypeptidase $\mathrm{M}$ (CPM), cyclin dependent kinase 4 (CDK4), and tetraspanin 31 (TSPAN31). Pleomorphic liposarcoma and DDLPS share overlapping HP features but have different cytogenetic and immunoexpression profile studies, so it is important to differentiate them [24].

Smith et al. studied the most frequent imaging findings of 24 women with the final diagnosis of primary breast sarcoma. The mammography identified in most patients a noncalcified oval nodule with indistinct margins. US examination revealed an oval, hypoechoic, and hypervascular solid mass with indistinct borders and posterior acoustic enhancement. MRI identified more often an oval or round nodule with irregular borders, high signal intensity on T2, and inhomogeneous enhancement [27].

Liposarcomas that do not contain specific features on mammograms are usually evaluated as fibroadenomas [2, $8,14]$. US assessment of liposarcoma has low diagnostic sensitivity due to the heterogeneous tumor appearance, and despite its hypervascular aspect on color Doppler imaging, it can be misdiagnosed as breast fibroadenoma or abscess $[3,8]$. The MRI investigation proves to have $100 \%$ sensitivity and $83 \%$ specificity in liposarcoma diagnosis [3]. Positron emission tomography (PET)-CT is a reliable diagnostic tool to distinguish between WDLPS and DDLPS, with $83.3 \%$ sensitivity and $85.7 \%$ specificity [28].

Using different imaging techniques, Nagarajan et al. showed the key elements (fat component, the presence of a solid/soft tissue component, internal vascularity) on mammogram and US for the differential diagnosis for primary breast liposarcoma with other benign or malignant tumors of the breast [21].

There is no definitive consensus regarding breast sarcoma treatment, current recommendations relying on small 
retrospective case reviews [11, 19, 29], and the treatment strategy extrapolated from other STS locations [29].

Yin et al. have published one of the biggest series of breast sarcomas in 785 women from the Surveillance, Epidemiology, and End Results (SEER) Program database, studying their clinicopathological features, treatment, and prognosis. They found that better survival outcomes are obtained with breast-conserving surgery than with mastectomy in M0 patients. Tumor size, grade, histology, and radiation history were important prognostic factors. They reported improved survival rates when adjuvant radiotherapy is used in tumors over $50 \mathrm{~mm}$ [11]. In our case, the tumor size was less than $50 \mathrm{~mm}$.

The most important treatment for breast sarcoma is surgery, which has the purpose of obtaining radical excision of the tumor with negative margins (R0) and avoiding local tumor recurrence linked to possible skip metastases [10, $11,29]$. Axillary lymph node dissection is unnecessary for patients with a low risk of lymph node metastasis [29]. To reach this goal, it is important to evaluate the tumor/ breast size ratio before surgery to properly plan the surgical strategy (mastectomy vs. quadrantectomy and the excision of possible skip metastases) without compromising the prognosis [10]. The role of radiotherapy after $\mathrm{R} 0$ resection is not clear, and there are no consensus criteria to establish who should get adjuvant radiotherapy. After mastectomy, there are benefits of radiation therapy in cases where it was difficult to achieve adequate safety margin in large-sized, deep-seated breast sarcomas, with a high risk of recurrence $[11,29]$. Patients must be followed-up for local recurrence and distant metastasis in the postoperative period [8].

The role of chemotherapy remains controversial. Despite the recent drug approval, the most efficient chemotherapy in STS remains Doxorubicin and Ifosfamide [30]. First-line chemotherapy includes Doxorubicin alone or in combination with Ifosfamide and Dacarbazine in advanced STS. Secondline options for patients with advanced STS include Pazopanib, Trabectedin, and Eribulin [30-32]. Trabectedin was approved to treat liposarcomas and leiomyosarcomas after anthracyclines, while Eribulin was for liposarcomas [31]. Adjuvant chemotherapy may provide a progressionfree survival benefit, while overall survival improvement data are still unclear.

The prognosis varies individually. Factors that affect local recurrence are positive surgical borders and pleomorphic type liposarcomas $[6,8]$. The relationship between tumor size and patient outcome (including local recurrence) is well known: tumors larger than $5 \mathrm{~cm}$ carry a worse prognosis than smaller ones [8]. The local recurrence is also related to the tumor size: it is $1.1 \%$ if the tumor size is less than $2 \mathrm{~cm}$; it increases at $1.7 \%$ when the tumor size is between $2.1 \mathrm{~cm}$ and $5 \mathrm{~cm}$, and to $6.1 \%$ if the tumor is larger than $5 \mathrm{~cm}$ [6]. Tumor grade, alongside mutation of tumor protein p53 (TP53) gene, nuclear overexpression of p53, and a high Ki67 proliferation index, are reported to be important HP prognostic factors in STSs [4].

Disease-free survival (DFS) rates range from $44 \%$ to $74 \%$ at five years following adequate surgery [8]. The overall survival results decrease in patients with distance metastasis, even after additional chemotherapy [6]. Overall survival rates were higher than DFS, ranging between $61 \%$ and $91 \%$ [8]. The five-year survival rate in liposarcomas of the breast is approximately $50 \%$ [6].

\section{ㅁ Conclusions}

Liposarcoma is a rare type of breast cancer. Despite its rarity, the differential diagnosis of any breast nodules should include it. The therapeutic plan is facilitated when a careful preoperative radiological and HP assessment makes a positive diagnosis. Surgery has the purpose of obtaining radical excision of the tumor with negative margins. Since lymphatic dissemination does not occur, axillary lymph node dissection is unnecessary in the great majority of cases. The dimension of the tumor, HP subtype, and clean surgical borders are important prognostic factors. Due to the small number of cases found in the literature, the best treatment choice and determination of prognosis are difficult to make; reporting any case is crucial. Our paper reports the first case of breast liposarcoma, the diagnosis, and therapy strides; the patient was successfully cared for towards a five-year tumor-free period.

\section{Conflict of interests}

The authors declare no conflict of interests.

\section{Acknowledgments}

The authors would like to gratefully acknowledge Dr Gabriela-Izabela Bălţătescu and Center for Research and Development of Malignant Pathology's Morphological and Genetic Studies (CEDMOG, Ovidius University, Constanţa) for help with generating scanning images used in this paper.

\section{References}

[1] Saito T, Ryu M, Fukumura Y, Asahina M, Arakawa A, Nakai K, Miura H, Saito M, Yao T. A case of myxoid liposarcoma of the breast. Int J Clin Exp Pathol, 2013, 6(7):1432-1436. PMID: 23826427 PMCID: PMC3693211

[2] Salhi H, Jaidane O, Bouhani M, Ben Hassouna J, Ben Dhieb T, Héchiche M, Rahal K. Primary liposarcoma of the breast: a report of 5 cases. Int Ann Med, 2017, 1(1):6. https://doi.org/ 10.24087/IAM.2017.1.1.6 https://www.semanticscholar.org/ paper/Primary-liposarcoma-of-the-breast\%3A-a-report-of-5Salhi-Jaidane/ed2eac9d420ef27cc1ef2ccc2d302a8bfb6033fc

[3] Raj SD, Rogers S, Del Junco GW, Sepulveda K. Dedifferentiated liposarcoma of the adult male breast. Radiol Case Rep, 2015, 9(2):906. https://doi.org/10.2484/rcr.v9i2.906 PMID: 27186240 PMCID: PMC4861833

[4] Cil T, Altintas A, Pasa S, Buyukbayram H, Isikdogan A. Primary spindle cell sarcoma of the breast. Breast Care (Basel), 2008, 3(3):197-199. https://doi.org/10.1159/000121469 PMID: 20824039 PMCID: PMC2931117

[5] Pant I, Kaur G, Joshi SC, Khalid IA. Myxoid liposarcoma of the breast in a 25 -year-old female as a diagnostic pitfall in fine needle aspiration cytology: report of a rare case. Diagn Cytopathol, 2008, 36(9):674-677. https://doi.org/10.1002/dc. 20913 PMID: 18677756

[6] Rodríguez Suárez I, Moguel N, Espejo R, Ríos N, Bautista V. Primary breast liposarcoma. OMICS J Radiol, 2017, 6(6):282. https://doi.org/10.4172/2167-7964.1000282

[7] Fletcher CDM, Bridge JA, Hogendoorn PCW, Mertens F (eds). World Health Organization (WHO) Classification of Tumours of Soft Tissue and Bone. $4^{\text {th }}$ edition, vol. 5, International Agency for Research on Cancer (IARC) Press, Lyon, France, 2013. https://publications.iarc.fr/Book-And-Report-Series/Who-Cla ssification-Of-Tumours/WHO-Classification-Of-Tumours-OfSoft-Tissue-And-Bone-2013

[8] Pencavel TD, Hayes A. Breast sarcoma - a review of diagnosis and management. Int J Surg, 2009, 7(1):20-23. https://doi.org/ 10.1016/j.ijsu.2008.12.005 PMID: 19114317

[9] Năsui B, Popa M, Curşeu D, Sîrbu D, lonuţ C. Ingestia de alcool in relaţie cu cancerul mamar [Correlation of alcohol intake with breast cancer]. Rev Med Chir Soc Med Nat lasi, 2009, 113(3):858-863. PMID: 20191845 
[10] Pasta V, Monti M, Cialini M, Vergine M, Urciuoli P, lacovelli A Rea S, D'Orazi V. Primitive sarcoma of the breast: new insight on the proper surgical management. J Exp Clin Cancer Res, 2015, 34(1):72. https://doi.org/10.1186/s13046-015-0190-1 PMID: 26219853 PMCID: PMC4518869

[11] Yin M, Mackley HB, Drabick JJ, Harvey HA. Primary female breast sarcoma: clinicopathological features, treatment and prognosis. Sci Rep, 2016, 6:31497. https://doi.org/10.1038/ srep31497 PMID: 27510467 PMCID: PMC4980597

[12] Al-Rikabi AC, El-Sharkawy MS, Al-Seif A. Primary well differentiated breast liposarcoma with divergent cartilagenous differentiation: a case report. Oman Med J, 2013, 28(2):138_ 140. https://doi.org/10.5001/omj.2013.37 PMID: 23599887 PMCID: PMC3628195

[13] Briski LM, Jorns JM. Primary breast atypical lipomatous tumor/ well-differentiated liposarcoma and dedifferentiated liposarcoma Arch Pathol Lab Med, 2018, 142(2):268-274. https://doi.org/ 10.5858/arpa.2016-0380-RSR2 PMID: 29372852

[14] O'Donnell ME, McCavert M, Carson J, Mullan FJ, Whiteside MW, Garstin WI. Non-epithelial malignancies and metastatic tumours of the breast. Ulster Med J, 2009, 78(2):105-112. PMID: 19568446 PMCID: PMC2699197

[15] Al-Benna S, Poggemann K, Steinau HU, Steinstraesser L. Diagnosis and management of primary breast sarcoma. Breast Cancer Res Treat, 2010, 122(3):619-626. https://doi.org/10. 1007/s10549-010-0915-y PMID: 20480227

[16] Austin RM, Dupree WB. Liposarcoma of the breast: a clinicopathologic study of 20 cases. Hum Pathol, 1986, 17(9):906913. https://doi.org/10.1016/s0046-8177(86)80640-2 PMID: 3019868

[17] Adem C, Reynolds C, Ingle JN, Nascimento AG. Primary breast sarcoma: clinicopathologic series from the Mayo Clinic and review of the literature. $\mathrm{Br} J$ Cancer, 2004, 91(2):237-241. https://doi.org/10.1038/sj.bjc.6601920 PMID: 15187996 PMCID: PMC2409972

[18] Klopcic U, Lamovec J, Luzar B. Fine needle aspiration biopsy of primary breast myxofibrosarcoma: a case report. Acta Cytol, 2009, 53(1):109-112. https://doi.org/10.1159/000325095 PMID 19248565

[19] Nandipati KC, Nerkar H, Satterfield J, Velagapudi M, Ruder U Sung KJ. Pleomorphic liposarcoma of the breast mimicking breast abscess in a 19-year-old postpartum female: a case report and review of the literature. Breast J, 2010, 16(5):537540. https://doi.org/10.1111/j.1524-4741.2010.00949.x PMID: 20604797

[20] Lee JY, Kim DB, Kwak BS, Kim EJ. Primary fibrosarcoma of the breast: a case report. J Breast Cancer, 2011, 14(2):156159. https://doi.org/10.4048/jbc.2011.14.2.156 PMID: 21847413 PMCID: PMC3148532

[21] Nagarajan B, Autkar G, Patel K, Sanghvi M. Primary breast liposarcoma. J Radiol Case Rep, 2018, 12(12):10-15. https:// doi.org/10.3941/jrcr.v12i12.3457 PMID: 31565160 PMCID: PMC6743859
[22] Jo SJ, Jung HK, Nam KH. Recurrent primary pleomorphic liposarcoma of the breast: a case report with imaging findings. J Breast Cancer, 2020, 23(5):567-573. https://doi.org/10.4048/ jbc.2020.23.e29 PMID: 33154832 PMCID: PMC7604378

[23] Chhieng DC, Cangiarella JF, Waisman J, Fernandez G, Cohen JM. Fine-needle aspiration cytology of spindle cell lesions of the breast. Cancer, 1999, 87(6):359-371. https://doi.org/ 10.1002/(sici)1097-0142(19991225)87:6<359::aid-cncr7>3.0. co;2-7 PMID: 10603190

[24] Whitsell T, Marcovis K, Ruhs S, Andres M, Beck S. Highgrade pleomorphic liposarcoma of the breast. Grand Rounds, 2011, 11:87-91. https://doi.org/10.1102/1470-5206.2011.0022

[25] Kammerer-Jacquet SF, Thierry S, Cabillic F, Lannes M, Burtin F, Henno S, Dugay F, Bouzillé G, Rioux-Leclercq N, BelaudRotureau MA, Stock N. Differential diagnosis of atypical lipomatous tumor/well-differentiated liposarcoma and dedifferentiated liposarcoma: utility of p16 in combination with MDM2 and CDK4 immunohistochemistry. Hum Pathol, 2017, 59:34-40. https://doi.org/10.1016/j.humpath.2016.08.009 PMID: 27597521

[26] Haddox CL, Riedel RF. Recent advances in the understanding and management of liposarcoma. Fac Rev, 2021, 10:1. https:// doi.org/10.12703/r/10-1 PMID: 33659920 PMCID: PMC7894267

[27] Smith TB, Gilcrease MZ, Santiago L, Hunt KK, Yang WT. Imaging features of primary breast sarcoma. AJR Am J Roentgenol, 2012, 198(4):W386-W393. https://doi.org/10.2214/ AJR.11.7341 PMID: 22451578

[28] Parkes A, Urquiola E, Bhosale $P$, Lin H, Watson K, Wang WL, Feig B, Torres K, Roland CL, Conley AP, Zarzour M, Livingston JA, Ratan R, Ludwig J, Araujo DM, Ravi V, Benjamin RS, Patel S, Somaiah N. PET/CT imaging as a diagnostic tool in distinguishing well-differentiated versus dedifferentiated liposarcoma. Sarcoma, 2020, 2020:8363986. https://doi.org/10.1155/2020/ 8363986 PMID: 32565716 PMCID: PMC7285404

[29] Hu QC, Mei X, Feng Y, Ma JL, Yang ZZ, Shao ZM, Yu XL, Guo XM. Early local recurrence presents adverse effect on outcomes of primary breast sarcoma: a retrospective study from single institute in China. Medicine (Baltimore), 2016, 95(1):e2422. https://doi.org/10.1097/MD.0000000000002422 PMID: 26735546 PMCID: PMC4706266

[30] Kawai A, Yonemori K, Takahashi S, Araki N, Ueda T. Systemic therapy for soft tissue sarcoma: proposals for the optimal use of Pazopanib, Trabectedin, and Eribulin. Adv Ther, 2017, 34(7):1556-1571. https://doi.org/10.1007/s12325-017-0561-4 PMID: 28547734 PMCID: PMC5504216

[31] Ratan R, Patel SR. Chemotherapy for soft tissue sarcoma. Cancer, 2016, 122(19):2952-2960. https://doi.org/10.1002/ cncr.30191 PMID: 27434055

[32] Recine F, Bongiovanni A, Riva N, Fausti V, De Vita A, Mercatali L, Liverani C, Miserocchi G, Amadori D, Ibrahim T. Update on the role of Trabectedin in the treatment of intractable soft tissue sarcomas. Onco Targets Ther, 2017, 10:1155-1164. https://doi.org/10.2147/OTT.S127955 PMID: 28260930 PMCID: PMC5328291

\section{Corresponding author}

Anca Lucia Pop, Lecturer, MD, PhD, Department of Clinical Laboratory, Carol Davila University of Medicine and Pharmacy, 37 Dionisie Lupu Street, Sector 2, 020021 Bucharest, Romania; Phone +40745-009 910, e-mails: anca.pop@umfcd.ro, ancapop@hotmail.com 